\title{
Sustainability Education and Organizational Change: A Critical Case Study of Barriers and Change Drivers at a Higher Education Institution
}

\author{
Edwin E. Akins II ${ }^{1}$, Elizabeth Giddens ${ }^{2}$, David Glassmeyer ${ }^{3}{ }^{(1)}$, Amy Gruss ${ }^{4}$, \\ Maria Kalamas Hedden ${ }^{5, *}$, Vanessa Slinger-Friedman ${ }^{6}$ and Matthew Weand ${ }^{7}$ \\ 1 Department of Architecture, Kennesaw State University, Kennesaw, GA 30144, USA; eakins1@kennesaw.edu \\ 2 Department of English, Kennesaw State University, Kennesaw, GA 30144, USA; egiddens@kennesaw.edu \\ 3 Department of Secondary and Middle Grades Education, Kennesaw State University, Kennesaw, GA 30144, \\ USA; dglassme@kennesaw.edu \\ 4 Department of Civil and Construction Engineering, Kennesaw State University, Kennesaw, GA 30144, USA; \\ agruss@kennesaw.edu \\ 5 Department of Marketing and Professional Sales, Kennesaw State University, Kennesaw, GA 30144, USA \\ 6 Department of Geography and Anthropology, Kennesaw State University, Kennesaw, GA 30144, USA; \\ vslinger@kennesaw.edu \\ 7 Department of Evolution, Ecology and Organismal Biology, Kennesaw State University, Kennesaw, GA \\ 30144, USA; mweand@kennesaw.edu \\ * Correspondence: mkalamas@kennesaw.edu
}

Received: 1 November 2018; Accepted: 1 January 2019; Published: 18 January 2019

\begin{abstract}
Integrating sustainability within institutions of higher education can have a tremendous impact on students, faculty, and the larger community. Sustainability efforts also experience many barriers to implementation within higher education contexts. A change management perspective can help characterize these barriers and ways to overcome them. In this critical case study, we use a process model to examine the kinds of barriers Kennesaw State University (KSU) has faced regarding implementation of academic sustainability and to evaluate change drivers that can advance sustainability during a time of leadership change. The process model evaluates barriers and change drivers according to published frameworks, and provides a way for higher education institutions to identify the most difficult barriers, easily surmountable barriers, and areas where change drivers can have the most impact. At KSU, the process model identified the self-determination of middle-tier change drivers as the most important way to advance sustainable development in higher education institutions (SD in HEI) until new leadership emerges. The process model is iterative and modifiable, because the specific frameworks used in the process model may vary depending upon the needs of each HEI and stage of progression toward SD.
\end{abstract}

Keywords: barriers to change; change drivers; critical case study; education for sustainability (EfS); faculty empowerment; higher education institutions; organizational change; sustainable development in higher education institutions (SD in HEI)

\section{Introduction}

Sustainable development in higher education institutions (SD in HEI, a synonym of education for sustainability, EfS) presents distinct challenges, which require an understanding of the inherent, multi-faceted complexity of sustainability and the interdisciplinary nature of the subject matter. "The analogy that 'being a leader of EfS is like trying [to] make a quilt' captures" the difficult role sustainability leaders must play [1] (p. 7). HEIs, like other organizations, rely on effective leadership to 
promote a sustainability culture. Scott et al. state that the crucial factor for advancing sustainability in $\mathrm{HE}$ is to build viable leadership capabilities, competencies, support systems, and pathways [1]. Instead, HEIs often face barriers and obstacles when it comes to SD such as being perceived as an abstract idea espoused by environmental and social activists, seeming disconnected from the institution's strategic objectives, and lacking resources and/or administrative support for implementation. One of these stumbling blocks, the absence of forward-looking transformative leadership, is especially detrimental to SD. According to recent work [2-4], environmentally specific transformational leadership directly and indirectly affects employees' pro-sustainability behaviors in the workplace. As such, leaders in HEIs can encourage or stifle employees' sustainability efforts through their leadership practices.

Beyond the important role of traditional leaders in instituting organizational change, "any employee who is able to successfully engage with others regarding sustainability issues can become a sustainability leader, environmental champion, or change agent" [5] (p. 250). To be viable and authentic, SD in university academics and campus operations must be coordinated, integrated, and mutually supported and implemented [6,7]. That is, achieving a reasonable level of orchestrated program functioning at a large public university requires the effort and good will of all members of the university community (operations managers, permanent and part-time staff, full- and part-time faculty, deans, academic directors, and students at all levels and in all fields of study). There should be "'a whole-of-university' approach to sustainability" [8] (p. 55). Because sustainability is such a broad concept, it is no surprise that many factors, and potentially many levels of leaders, are needed to implement SD $[9,10]$.

Currently, discourse in SD in HEI literature exists that considers whether leadership must be the traditional "top-down" variety or if it can follow a distributed leadership approach. Change agents at the faculty and staff levels can enact "'middle-out' change" [11] (p. 340). This concept refers to change that relies on collaboration, institutional know-how, political savvy, and patience but is not high profile. According to Brinkhurst et al., these middle-ground change agents are "social intrapreneur[s]" [11] (p. 344), whose entrepreneurial spirit can bring positive change to a university and make headway where progress is stalled. Although engagement and involvement of rank and file members matters in organizations [5], bringing about change through empowerment is the focus of this research. Specifically, the research team considered empowerment as a change driver and the role it plays in helping faculty overcome the barriers they face in the integration of SD. Taking an organizational change management perspective, the authors focused solely on faculty at Kennesaw State University as change agents.

In the conceptual framework, we summarized the organizational change literature as it pertains to the barriers and drivers related to implementing SD in HEIs. We also developed a holistic framework for overcoming barriers to change using employee empowerment. Following a five-phase assessment of the current status of SD at Kennesaw State University (KSU), we identified the barriers and drivers to change. Using a structured approach to analyzing and prioritizing the barriers to change and the related effects of empowerment, we developed a generalizable process model of change in HEIs looking to implement sustainability.

\section{Conceptual Framework: A Change Management Perspective}

\subsection{Organizational Change in HEIs: Barriers and Change Drivers}

The organizational change literature reports both barriers and drivers that affect the implementation of SD in HEIs. Among the most important barriers to change, Aleixo et al. [12] list issues with the concept of sustainability and the rigid structure of HEIs, a lack of commitment among faculty and other university stakeholders coupled with resistance to change, and a lack of resources and know-how. Verhulst and Lambrechts [13] (p. 191) also summarize the barriers to change found in the extant literature by dividing them into three broad clusters, namely, (1) those "related to lack of awareness," (2) those "related to the structure of higher education," and (3) those "related to 
the lack of resources." Since these three groupings encompass the ones mentioned by Aleixo et al. [12], we applied them to our institution of higher learning.

Prominent among the barriers to change are the human factors, or as some call people, the "soft side" of the HEI. As obstacles to change, people play a special role, one that has long been established in the organizational change literature (for a review pertaining to sustainability, see Verhulst, 2012 [14]). While these human factors may serve as deterrents to change, people can also be effective change agents. In fact, several researchers argue for the need to study the human factors as a means of effective organizational change in HEIs (e.g., $[13,15])$. Going a step further, Verhulst and Boks [16] focus on employee empowerment as a change driver or success factor. Drawing from the management literature, they describe employee empowerment using three dimensions: "authority[,]" "resources and specialization[,]" and "self-determination" [16] (p. 75). For HEIs looking to integrate SD, empowerment is one of the main motivators for effective organizational change [15]. Employee empowerment is a motivational tool whereby administrators, faculty, staff, and others become sustainability proponents. In practical terms, organizational change through empowerment means addressing all three dimensions (i.e., authority, resources and specialization, and self-determination) [15], essentially, the success factors. As critical success factors leading to organizational change in HEIs, the dimensions of employee empowerment thus deserve further study.

To understand the process of organizational change, both the barriers and the change drivers deserve attention. We therefore combined two theoretical frameworks: (1) the categorization of the barriers to change [13] and (2) empowerment as a change driver $[15,16]$ into one holistic framework. The approach in this work used empowerment to overcome the barriers to sustainability implementation in HEIs and, ultimately, drive change (for a depiction, see Figure 1). In building upon these theoretical frameworks, this work contributes to the literature.

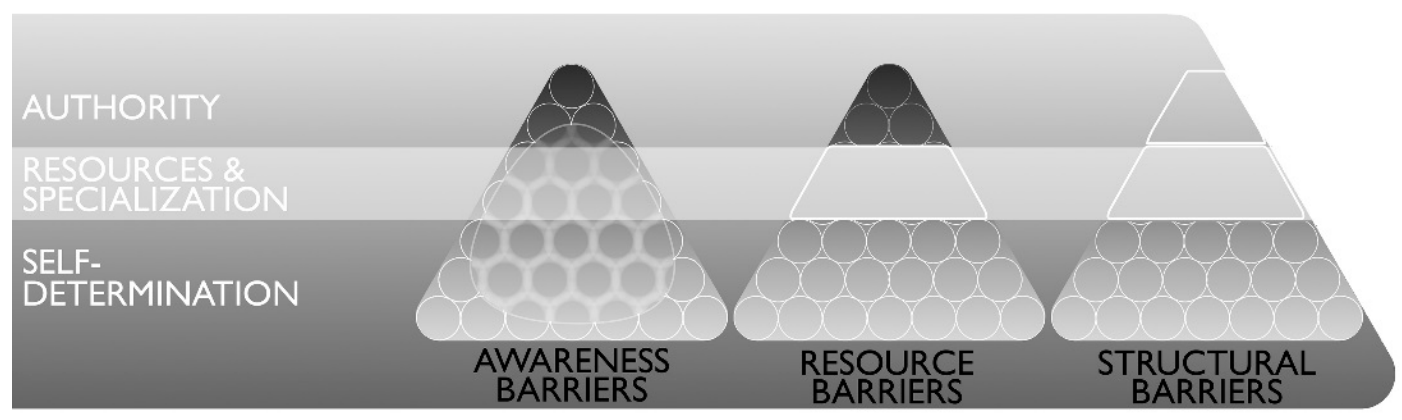

Figure 1. Overcoming barriers to change through faculty empowerment. Source: Research Team.

\subsection{Organizational Change in HEIs: A Process Model}

Referring to SD in HEIs, Brinkhurst et al. state that "changes have been achieved, but the processes underlying them are rarely examined. Consequently, it is difficult to ascertain which type of approach facilitates effective change in these complex organizations" [11] (p. 338). Barth [17] echoes this gap in the literature and calls for more generalizable process models that indicate how barriers to change and change drivers affect each other. By identifying the barriers to change, analyzing their type and difficulty, identifying change drivers and their degree of challenge, assessing which barriers should be addressed with which change drivers soonest for largest impact, and creating a plan for working on all barriers over time, our process model addressed this important gap in the literature. In treating the barriers and the drivers as dynamic variables, our process model captured the complexity of the change process in HEIs.

To develop a generalizable process model, we employed a critical case study. The goal was to learn from the shortcomings and virtues of the authors' institution in order to help other HEIs in their quest for SD change. In this light, we include a brief history of academic sustainability at KSU before moving to the methodology. 


\section{Context: KSU Academic Sustainability Efforts Before 2017}

KSU is situated in north Metro Atlanta, Georgia (USA). It was created from a 2014 consolidation of two smaller universities, each with over a decade of previous commitments to sustainability initiatives and research. With two campuses and a larger suite of degree offerings, the consolidated KSU committed itself to sustainability initiatives both in its facilities and their operation and in the university's educational mission. KSU has a history of sustainability programs and efforts, and is a signatory to multiple nation- and state-wide higher education sustainability agreements. Within the university, KSU established a Climate Commitment Council in 2008, reconceived in 2013 as the Presidential Commission on Sustainability, to advance and coordinate all aspects of sustainability. The university also created the position of director of sustainability in 2008 , specifically to promote sustainability across the curriculum, preserve natural areas, promote energy efficiency, and improve recycling programs [18]. In January 2016, KSU added a full-time sustainability program support coordinator to manage and monitor the work of the university staff in making the two campuses and their operations as sustainable as feasible.

During its first decade, the Commission made advances in operational sustainability. It collected data about campus facilities and operations to set baselines, benchmarks, and goals for energy and water use, recycling, waste reduction, and transportation improvements as well as considering sustainable policies in other areas of concern such as purchasing, landscaping, and natural areas. These data were used to plan improvements and to draft multiple yearly reports documenting progress toward sustainability benchmarks like KSU Greenhouse Gas Inventories and Climate Action Plans in 2014,2015 , and 2016. It also became an outlet through which sustainability-focused faculty, staff, and facilities personnel could network, share information about their sustainability-related projects and events, and garner support from one another.

Until the director's retirement in 2017, the trajectory of academic sustainability at KSU was ascending in parallel with operational sustainability, achieving successful initiatives in the faculty and student body. The director established a faculty workshop in 2009 to encourage an integrative sustainability pedagogy across the university's curriculum. Over eight years, it enrolled 77 faculty in 10 colleges and guided them in creating examples, lessons, assignments, and projects related to the intertwined environmental, economic, and social dimensions of sustainability. In addition, the director established a sustainability faculty fellow program in 2016. The fellows designed and executed academically focused year-long projects that strengthened faculty engagement in sustainability teaching and research. The fellows' projects often involved students as assistants or participating class members, consequently deepening student awareness and engagement university-wide.

To target the student body, the director created "Sustainability at KSU" as a cross-listed biology and environmental studies course, which was well enrolled and very popular with students. For example, one undergraduate who took this course became so passionate about promoting sustainability on campus that she created the Green Ambassadors student club, and it has become an important locus of student involvement in spreading student awareness of sustainability and supporting sustainable practices such as recycling, water conservation, reducing carbon emissions, and addressing food insecurity.

Across the board, from 2008 to 2017, the university supported what AASHE has identified as "an opportunity and a responsibility" to help transform society into a sustainable one in Beyond the Right Thing to Do: The Value of Sustainability in Higher Education [19] (p. 3). Reflection on the first decade of KSU efforts in academic sustainability would find that these sustainability efforts strengthened community and faculty relations, attracted students and prepared them for responsible citizenship, and advanced unification of "the campus around a shared sense of purpose" [19] (p. 4). This reflection is important because it provides an opportunity for assessing the human factors and obstacles that are influential in the integration of SD in this HEI. Furthermore, the insights garnered from the reflection process provide the foundation for our analysis. 


\section{Methods}

In applied disciplines like engineering and business, case studies are popular educational and research tools. The same holds true in the social sciences in general and in the study of SD in HE in particular (for the advantages of case-study methodology in the social sciences, see George and Bennett [20]). According to Hoover and Harder, "case[-]study methodology has become one of the most common qualitative approaches in research on sustainability in HE" for it captures the complex nature and fluid boundaries of sustainability in academia [21] (p. 176). Case studies are a powerful method to convey the "sustainability story" of a university in ways that help define problems and help effect change [21]. These features make the case study an ideal research tool for examining sustainability within higher education [22]. Following suit, the research team applied the case-study methodology to a major southeastern university's sustainability quest. The approach, however, differed from the traditional case-study methodology in two ways: (1) it brought together two major theoretical frameworks and then applied them to KSU (see Section 2), and (2) it developed an overarching process model of organizational change for sustainability. Both of these contributions are in line with calls for case studies not only to make recommendations and provide strategic direction but also "to develop models or frameworks" that address the context-specific nature of sustainability in HEIs and the ensuing organizational change [21] (p. 177).

The team undertook a qualitative case study because of this design's "particularistic, descriptive, and heuristic" features [23] (p. 29). Specifically, this study focused on a specific situation of sustainability at a single institution of higher education (particularistic), included analysis of several variables, and their interplay, over time (descriptive), and aimed to enhance and extend a reader's understanding of the barriers to sustainability at an institution of higher education (heuristic) [23]. Corcoran et al.'s work [22] was integrated to ensure that the work met the criteria for a critical case study. Specifically, the team examined Corcoran et al.'s set of critical considerations for conducting case-study research in sustainability in higher education.

Focusing on SD at an HEI, KSU, the critical case study analyzed both the barriers and the change drivers to organizational change. To characterize the types of barriers based on Verhulst and Lambrechts' change-management theory [13], the team used the descriptions of each of the three elements of barriers to code the institutional information compiled. As outlined by Corcoran et al. [22] (p. 17), this task involved gathering information related to "the ecological, social[,] and economic dimensions of sustainability." Following Yin's definition of a case study, the team used "multiple sources of evidence" [24] (p. 23). This information included (1) KSU's mission and purpose of the institution, (2) curriculum and academic disciplines, (3) KSU faculty research, (4) KSU operations, (5) student opportunities, (6) faculty and staff development and awards/incentives, and (7) outreach and local community.

Additionally, a survey was administered to all KSU faculty to gather specific information on faculty perspectives on sustainability efforts at KSU and to identify barriers caused by a lack of awareness. An online survey was created to answer basic questions about faculty views of sustainability. The survey, "Sustainability-Related Attitudes and Behaviors among Faculty (Study 18-487)," was administered in late April and early May 2018 and completed by 467 individuals out of 1277 full-time faculty, a participation rate of almost 37 percent. The results of the survey participation were completely anonymous and no identifiers were collected from respondents. Survey questions were vetted through the Institutional Review Board to ensure unbiased examination.

As expected, not all descriptions within each barrier were pertinent to KSU. Therefore, specific barriers observed at KSU were delineated with a check mark in Table 1. For each SD barrier, corresponding empowerment-based actions taken by the KSU faculty were identified. Although identification of barriers and change drivers described the current climate at an HEI, it did not provide a plan or indicate an action that needed to be taken in order to break through the current barriers. Therefore, additional assessment was needed in order to initiate SD at HEI. This research characterized 
the barrier and empowerment findings in order to identify the impact of each change driver and, thus, determine the potential to overcome a barrier and implement SD.

Table 1. Change Barriers at KSU. Source: Comprehensive list of barriers adopted from Verhulst and Lambrechts [13].

\begin{tabular}{lc}
\hline \multicolumn{1}{c}{ Barriers to Change } & Present at KSU \\
\hline Related to Lack of Awareness & $\checkmark$ \\
1. Lack of interest and involvement of the majority of the students and staff members & $\checkmark$ \\
2. Lack of support by management and policy makers & $\checkmark$ \\
3. Lack of professionalization and training of teachers & $\checkmark$ \\
4. Lack of policy making in order to promote sustainability & $\checkmark$ \\
5. Lack of standard definitions and concepts of sustainable development (SD) in higher education (HE) & \\
6. Lack of recognition, change agents for SD are often not taken seriously & $\checkmark$ \\
7. SD seen as a threat to academic freedom and credibility & $\checkmark$ \\
8. SD is not seen as relevant to a certain course or discipline & \\
\hline Related to the Structure of Higher Education & $\checkmark$ \\
9. Conservative disciplinary structure of HE institutions (HEIs), barely open to new paradigms & $\checkmark$ \\
10. Inefficient communication and shared information both top-down and bottom-up & $\checkmark$ \\
11. Resistance to change by education and research & $\checkmark$ \\
12. Focus on short-term profit as a result of managerial thinking and policy making in HE & $\checkmark$ \\
13. Lack of interdisciplinary research as a result of insufficient coordination and cooperation & \\
14. Overcrowded curriculum & $\checkmark$ \\
15. Focus on content-based learning & \\
\hline Related to the Lack of Resources & \\
16. Lack of money, SD is not seen as a priority for funding & \\
17. High work pressure and lack of time; SD is often combined with other tasks \\
18. Lack of access to information, due to absence of measuring instruments or by unwillingness of staff \\
19. Lack of consistent legislation (phrased in this work as policy support from governing bodies) \\
20. Lack of qualitative and quantitative performance indicators \\
21. Technical problems
\end{tabular}

\section{Results}

The five-phase assessment of the current status of SD at KSU led to a list of barriers and associated change drivers, displayed in Table 2. The assessment phases were (1) identification of relevant barriers from Verhulst and Lambrechts [13], (2) identification of specific KSU barriers, (3) identification of change drivers at KSU, (4) designation of when the barrier emerged, and (5) the degree of significance or impact of each item (for a depiction of the process model, see Figure 2).

Once the research team observed that barriers specific to KSU often included all three elements from Verhulst and Lambrechts (i.e., awareness, structure, and resources), it organized the list so that the multiple dimensions of each barrier at KSU would be captured. KSU-specific barriers appeared in the far-left column, and the relevant elements from Verhulst and Lambrechts (V \& L) were noted in the next three left-hand columns. (V \& L cells without any text indicate that they were not relevant to KSU barriers; these were marked with an X.) In response to the barriers, current actions by the KSU sustainability community were included in the three right-hand columns. They were organized according to their origin: whether they arose from authority, on-hand resources and specialization, and/or self-determination. Barriers in existence before 2017 were listed at the top of the table, and those arising between 2017 and 2018 were placed at the bottom of the table.

Although this display of barriers and change drivers was useful, it suggested that all of the barriers were of equal significance and that all of the change drivers were of equal impact, which was not the case. Importantly, most barriers had no change driver in the "authority" category. Consequently, a subsequent step was added to characterize the degree of significance of the barriers and the significance or impact of each change driver in overcoming the barrier. This characterization was indicated by shading the cells of the table in order to provide an immediate visual of the difficulty of overcoming a barrier and the corresponding impact that identified change drivers had in response to the barrier. Cells with darker shading show a high degree of significance or impact, those with light shading 
indicate a moderate degree of significance or impact, and those with no shading indicate a low degree of significance or impact. When no change driver was listed in a cell, no action was occurring to address the related barrier, and these cells appeared with darker shading because the absence of any impact was highly significant. This design allowed the team to see at a glance the cells where change drivers were underway and those where barriers were unaddressed. In the barrier columns, the lighter the area, the less significant the current challenge. In the change-driver columns, the lighter the area, the more was being done to address the barrier though the impact of these efforts was low. Light shading indicated moderate impact, which was possible when administrators funded events or recognized SD. Dark shaded change-driver cells indicated areas that were of great significance but had no empowerment efforts underway. This step revealed the following about KSU barriers:

1. Five of 10 barriers were of high significance; $5 / 10$ barriers were of moderate significance. There were no low-significance barriers.

2. Six of 10 barriers had three dimensions; $3 / 10$ had two dimensions, $1 / 10$ had one dimension. KSU barriers were complex.

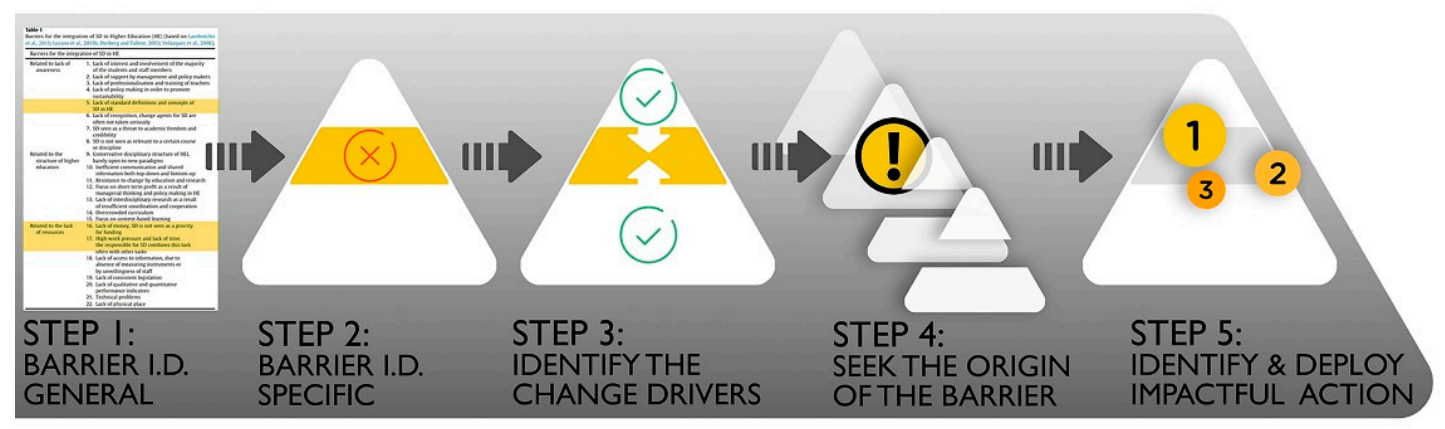

Figure 2. Process model of change in higher education institutions (HEIs) looking to implement sustainable development (SD). Source: Research Team.

This step revealed the following about KSU change drivers:

1. Only one moderate-level change driver existed in the authority dimension; this dimension was missing in nine change-driver cells. The absence of authority change drivers showed how current SD change agents were limited in their power.

2. No existing change drivers were of high impact. Sixteen of 17 existing change drivers were of moderate impact; $1 / 17$ was of low impact.

3. Only $2 / 10$ self-determination cells had no change driver; if actions existed in these cells, one (about university-wide funding) would be significant, but the other (about the state emphasis on student retention, degree progression, and timely graduation) would likely have only low impact because SD advocates were unlikely to influence state-level oversight at the Board of Regents. 
Table 2. Current Assessment of Barriers and Change Drivers Using the Conceptual Model (2017-2018). Source: Research Team.

\begin{tabular}{|c|c|c|c|c|c|c|}
\hline & \multicolumn{3}{|c|}{ Verhulst \& Lambrechts' Barriers to Integration of SD in HEI } & \multicolumn{3}{|c|}{ Dimensions of Empowerment as a Change Driver } \\
\hline Barriers at KSU & Awareness & Structure & Resources & Authority & Resources \& Specialization & Self-Determination \\
\hline \multicolumn{7}{|c|}{ Barriers Existing Before 2017} \\
\hline $\begin{array}{l}\text { Narrowly disciplinary \& } \\
\text { unintegrated SD concept }\end{array}$ & $\begin{array}{l}\text { (5) Lack of standard definitions \& } \\
\text { concepts of SD in HE } \\
\text { (8) SD is not seen as relevant to a } \\
\text { certain course or discipline }\end{array}$ & $\begin{array}{l}\text { (9) Conservative } \\
\text { disciplinary structure } \\
\text { of HEI, barely open to } \\
\text { new paradigms }\end{array}$ & $\begin{array}{l}\text { (16) Lack of money; SD is not seen } \\
\text { as a priority for funding } \\
\text { (17) High work pressure \& lack of } \\
\text { time; the responsibility for SD } \\
\text { tasks is combined with other tasks } \\
\text { (19) Lack of consistent [policy } \\
\text { support from governing bodies] }\end{array}$ & $\begin{array}{l}\text { - No } \\
\text { change driver }\end{array}$ & $\begin{array}{l}\text { Use of broad \& } \\
\text { interdisciplinary UN } \\
\text { Sustainability Goals to frame } \\
\text { funded campus events such } \\
\text { as Equinox Week. } \\
\text { Demonstrate how SD } \\
\text { curriculum meets university } \\
\text { strategic goals of } \\
\text { transformational learning \& } \\
\text { action step of } \\
\text { high-impact teaching. }\end{array}$ & $\begin{array}{l}\text { - Active participation of SD } \\
\text { change agents in SD } \\
\text { campus events. }\end{array}$ \\
\hline $\begin{array}{l}\text { SD not part of general education or } \\
\text { career development for all } \\
\text { students; Faculty \& administrators } \\
\text { view SD as relevant only to a few } \\
\text { disciplines (e.g., biological sciences, } \\
\text { engineering, \& architecture) The } \\
\text { relevance to arts, humanities, } \\
\text { social sciences, business, \& } \\
\text { education is not broadly accepted. }\end{array}$ & $\begin{array}{l}\text { (2) Lack of support by } \\
\text { management \& policy makers } \\
\text { (4) Lack of policy making to } \\
\text { support DD } \\
\text { (8) SD is not seen as relevant to a } \\
\text { certain course or discipline }\end{array}$ & $\begin{array}{l}\text { (9) Conservative } \\
\text { disciplinary structure } \\
\text { of HEI, barely open to } \\
\text { new paradigms } \\
\text { (10) Inefficient } \\
\text { communication \& } \\
\text { shared information } \\
\text { both top-down \& } \\
\text { bottom-up } \\
\text { (15) Focus on } \\
\text { content-based } \\
\text { learning }\end{array}$ & $\begin{array}{l}\text { (19) Lack of consistent [policy } \\
\text { support from governing bodies] }\end{array}$ & $\begin{array}{l}\text { - } \begin{array}{l}\text { No } \\
\text { change driver }\end{array} \\
\text {. }\end{array}$ & $\begin{array}{l}\text { Demonstrate how SD } \\
\text { curriculum meets university } \\
\text { strategic goals of } \\
\text { transformational learning \& } \\
\text { action step of } \\
\text { high-impact teaching. } \\
\text { Events such as Equinox Week } \\
\text { that highlight the } \\
\text { interdisciplinarity of SD. } \\
\text { Use of commission meetings } \\
\text { as a forum to inform } \\
\text { university leaders. }\end{array}$ & $\begin{array}{l}\text { - Collaboration of faculty to } \\
\text { demonstrate } \\
\text { interdisciplinarity (e.g., } \\
\text { team-taught courses \& } \\
\text { projects). } \\
\text { - External publication by an } \\
\text { interdisciplinary team of } \\
\text { faculty. Risky move for junior } \\
\text { faculty with conservative } \\
\text { department chairs \& deans. } \\
\text { Curriculum planning by } \\
\text { Faculty Learning Community } \\
\text { (FLC). }\end{array}$ \\
\hline $\begin{array}{l}\text { SD has no university-wide } \\
\text { academic funding }\end{array}$ & $\begin{array}{l}\text { (2) Lack of support by } \\
\text { management \& policy makers } \\
\text { (4) Lack of policy making to } \\
\text { support SD }\end{array}$ & & $\begin{array}{l}\text { (16) Lack of money; SD is not seen } \\
\text { as a priority for funding }\end{array}$ & $\begin{array}{l}\text { - No } \\
\text { change driver }\end{array}$ & $\begin{array}{l}\text { Use of commission meetings } \\
\text { as a forum to inform } \\
\text { university leaders. }\end{array}$ & - No change driver \\
\hline
\end{tabular}


Table 2. Cont

\begin{tabular}{|c|c|c|c|c|c|c|}
\hline & \multicolumn{3}{|c|}{ Verhulst \& Lambrechts' Barriers to Integration of SD in HEI } & \multicolumn{3}{|c|}{ Dimensions of Empowerment as a Change Driver } \\
\hline Barriers at KSU & Awareness & Structure & Resources & Authority & Resources \& Specialization & Self-Determination \\
\hline \multicolumn{7}{|c|}{ Barriers Existing Before 2017} \\
\hline $\begin{array}{l}\text { No state-level policy support for } \\
\text { SD from the Board of Regents that } \\
\text { oversees the university }\end{array}$ & $\begin{array}{l}\text { (2) Lack of support by } \\
\text { management \& policy makers } \\
\text { (4) Lack of policy making to } \\
\text { support SD }\end{array}$ & & $\begin{array}{l}\text { (19) Lack of consistent [policy } \\
\text { support from governing } \\
\text { bodies] }\end{array}$ & $\begin{array}{l}\text { - No } \\
\text { change driver }\end{array}$ & $\begin{array}{l}\text { Use of commission meetings } \\
\text { as a forum to inform } \\
\text { university leaders. }\end{array}$ & $\begin{array}{l}\text { - Faculty advocacy for a return } \\
\text { of university support for SD } \\
\text { because of its new status as } \\
\text { an } R 2 \text { institution, aligning the } \\
\text { institution more fully with } \\
\text { others in its class. }\end{array}$ \\
\hline $\begin{array}{l}\text { No clearinghouse for faculty with } \\
\text { SD research interests to meet \& } \\
\text { collaborate }\end{array}$ & $\begin{array}{l}\text { (2) Lack of support by } \\
\text { management \& policy makers } \\
\text { (4) Lack of policy making to } \\
\text { support SD }\end{array}$ & $\begin{array}{l}\text { (10) Inefficient } \\
\text { communication \& shared } \\
\text { information both } \\
\text { top-down \& bottom-up }\end{array}$ & $\begin{array}{l}\text { (17) High work pressure \& lack } \\
\text { of time; the responsibility for } \\
\text { SD tasks is combined with } \\
\text { other tasks. }\end{array}$ & $\begin{array}{ll}\text { - } & \begin{array}{l}\text { No } \\
\text { change driver }\end{array}\end{array}$ & $\begin{array}{l}\text { Demonstrate that SD research } \\
\text { is what strategic plan } \\
\text { describes as "purposeful and } \\
\text { relevant research" worthy of } \\
\text { university support. }\end{array}$ & $\begin{array}{l}\text { A survey of faculty, which } \\
\text { has drawn attention to the } \\
\text { range of disciplines engaged } \\
\text { in SD issues, teaching content, } \\
\text { \& research. }\end{array}$ \\
\hline $\begin{array}{l}\text { Low awareness of SD award } \\
\text { winners \& their achievements }\end{array}$ & $\begin{array}{l}\text { (6) Lack of recognition; change } \\
\text { agents for SD are often not taken } \\
\text { seriously }\end{array}$ & $\begin{array}{l}\text { (10) Inefficient } \\
\text { communication \& shared } \\
\text { information both } \\
\text { top-down \& bottom-up }\end{array}$ & & $\begin{array}{l}\text { - } \begin{array}{l}\text { No } \\
\text { change driver }\end{array}\end{array}$ & $\begin{array}{l}\text { - Use of commission meetings } \\
\text { as a forum to inform } \\
\text { university leaders. } \\
\text { Gratitude for faculty awards } \\
\text { \& participation in } \\
\text { existing programs. }\end{array}$ & $\begin{array}{l}\text { Commission members' \& } \\
\text { others' diplomatic but } \\
\text { specific advocacy for } \\
\text { renewed university support } \\
\text { for SD. }\end{array}$ \\
\hline
\end{tabular}


Table 2. Cont

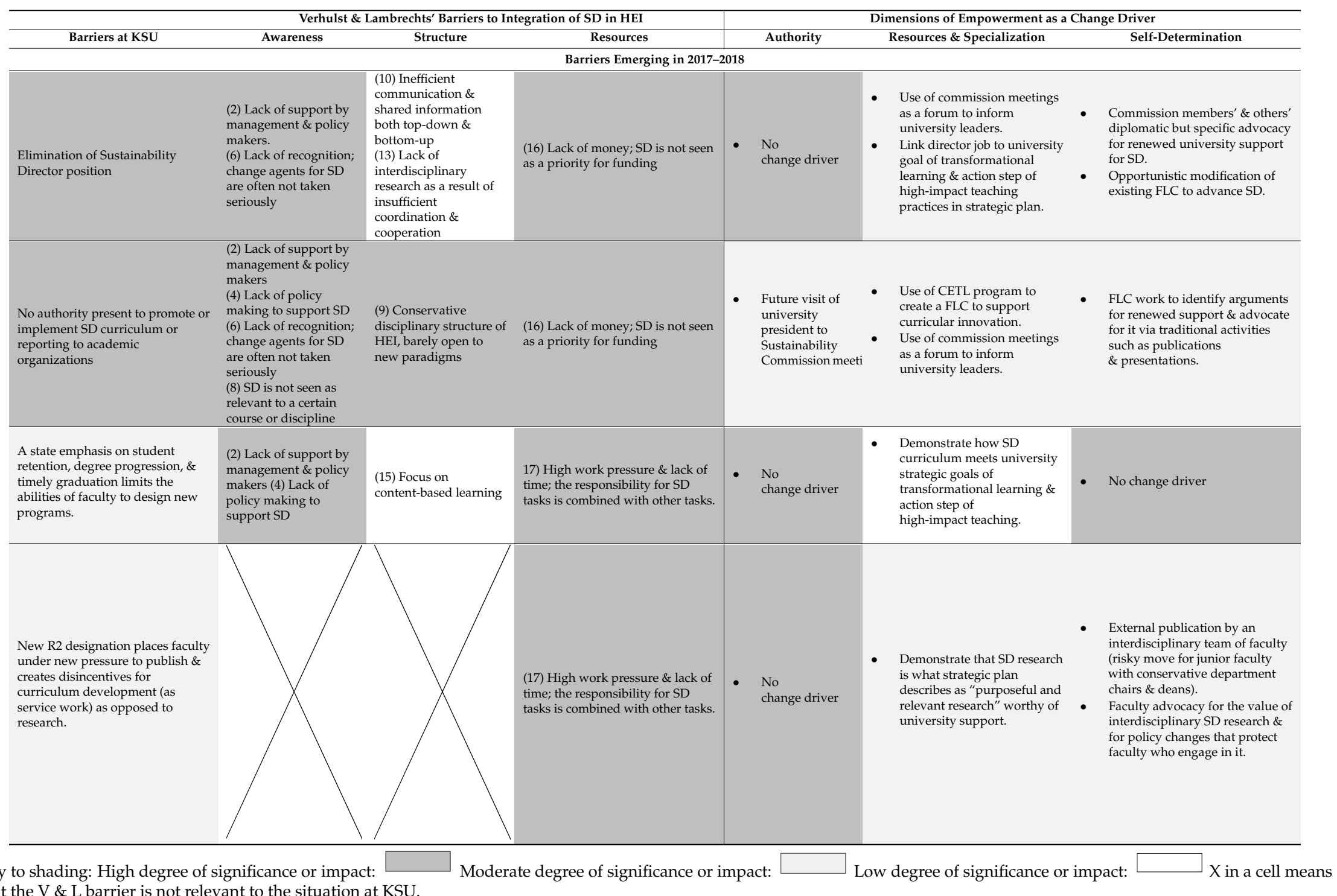

Key to shading: High degree of significance or impact:
that the V \& L barrier is not relevant to the situation at KSU. 


\section{Discussion}

In developing a process model for SD in HEIs (Figure 2), we addressed "the need for more theory-building and generalization" [17] (p. 162). From a theoretical perspective, our process model built on existing work by combining a comprehensive list of barriers with three dimensions of empowerment into a holistic framework. From a generalizability standpoint, our process model provided a useful tool for driving change at other HEIs. Although the interpretation of both the size of barriers and the adequacy of the change drivers was specific to KSU, the process was valuable for the research team in determining its strategy for moving forward. The same holds true for other HEIs that can use the same process for their own strategic purposes. The process model developed here also presents several benefits for addressing transformative organizational change at HEIs. Principally, it provides a structured method to analyze and prioritize barriers to change, and the related impact of empowered efforts on the pathway toward integration of SD. The benefits of the process model in relation to each of the three dimensions of empowerment are discussed below.

By placing barriers within an empowerment framework, the process model helps identify those barriers that are the most significant and difficult to overcome. The framework allowed the team to identify ways in which some KSU barriers presented difficulty in multiple dimensions because they were related to a lack of awareness, structure in HE, lack of resources, or a combination of those factors. We found that 50 percent of the barriers were of high significance and 60 percent involved three dimensions (Table 2), pointing to the complexity of KSU's barriers in general.

Among them, it was obvious that the most significant barrier to integrating SD at KSU was the retirement of and failure to replace the director of sustainability. This barrier was highly significant because it affected virtually all aspects of empowerment through authority. The long-established director position was eliminated in the spring of 2018. It had created a point person for university-wide $\mathrm{SD}$, but after the person who had held the job retired, support from the Academic Affairs Office declined in awareness (understanding the value of the position), structural support (an authority and a locus of SD activity), and resources (the time and focus to advance SD). With no one assigned to report to the university president about sustainability or lead university-wide efforts, the academic branch of KSU's sustainability effort met with significant setbacks that jeopardized its upward trajectory in gaining participation of both faculty and students on its campuses. The vital role that the KSU faculty had played, and needed to continue playing, to seek academic sustainability benefits was placed at risk. KSU was once a state leader in sustainability, but it no longer is, having been surpassed by both nearby private institutions and by sister public institutions such as the University of Georgia, Georgia Southern University, and University of West Georgia. These institutions have reliable financial support, academic sustainability directors, and either certificates or concentrations available to all undergraduates.

Research in SD routinely concludes that the support of a university's leadership is important to establishing academic sustainability instruction and campus-wide resources for students and faculty $[25,26]$. Barth goes so far as to state that "active top-down support is essential" [25] (p. 142). To create a thriving environment for sustainability, university leadership needs to establish a vision of campus sustainability and support it consistently for it to take root and flourish. Leadership's role includes building a team with a collective vision, taking action from that vision, and using the vision to empower the campus. A vision of sustainability has the potential to stall or fail at any of these junctures [27]. In KSU's case, sustainability efforts stalled when the former director of sustainability retired and the university experienced successive changes in upper administration. Lacking leaders who share a "sustainability ethos" [27] (p. 80), the state of SD at KSU is in question. To commit to SD, the university needs future-oriented, transformative, and silo-busting leaders who make sustainability a priority [1]. Like other HEIs, KSU needs leaders who empower employees to forge ahead in their sustainability quest and change agents who see the worth in educating future generations about sustainability. Rather than seeing a lack of authority as insurmountable, empowered faculty can effect change through other dimensions of empowerment. 
Another benefit of the process model is that it allowed us to identify barriers that are more easily surmountable (i.e., the "low-hanging fruit") and where change drivers can address multiple barriers and therefore have the greatest impact. Below we describe a few examples of these barriers and how they can be addressed through resources and specialization and through self-determination.

For KSU the most important resources include university policies, and venues that provide opportunities for networking among different organizational units. As an example of a relatively easily surmountable barrier, KSU faculty had no mechanism to become aware of each other's sustainability research efforts and therefore develop SD collaborations (see Table 2; row "No clearinghouse"), despite widespread interest in sustainability as indicated by our survey. Therefore, the creation of this clearinghouse is an obvious next step and it should be supported by the KSU strategic plan, which includes support for purposeful and relevant research (suitably broad). In this regard, any existing organizational policy that contains missions or goals supporting the advancement of SD is a valuable resource. Creating the clearinghouse could include something as simple as publishing the sustainability-related research activity of faculty on the KSU Sustainability website (the website already exists and requires minimal investment of additional resources). While this act has a relatively low impact, it could be used to start a coordinated SD network for research and teaching at KSU.

As an example of where resources and specializations can address multiple barriers, KSU's narrowly disciplinary and unintegrated concept for SD comprised six separate V\&L barriers, so it is a major impediment to an integrated curriculum program (such as an academic sustainability certificate available to all students across all majors). SD advocates who are full-time faculty, can respond meaningfully to this multi-faceted barrier by highlighting the interdisciplinarity inherent in current university-wide events. For example, KSU already holds an annual "Equinox Week" celebration and symposium organized according to the UN Sustainability Goals, and this allows disparate departments to network. Here again, policy is an important resource. Faculty can demonstrate that SD in general and a certificate in particular would aid the university in pursuing its Strategic Plan. This plan includes the goal of transformational learning and an action step of high-impact teaching; in turn, these are linked in university documents to student research projects, internships, and project- and service-learning [28]. By using the university-approved terminology and by emphasizing the relevance of SD to its new plans, advocates can demonstrate that SD is a broad content-based mechanism toward "transformational learning" because students value education that they readily identify as relevant to their personal life choices, their career options, and the quality of life in their globally connected communities.

Meetings of the KSU Presidential Commission on Sustainability were also identified as a networking resource that could address multiple barriers. The meetings are vital to the success of SD because they are the primary venue for sharing pertinent information among disparate branches of the university. Members of the Commission include students, faculty, administration, and staff representing a wide array of different disciplines and operational divisions. Importantly, anyone can attend and present at these meetings. The meetings are also a key venue for interaction with authorities including the university president. While the new KSU president has not yet attended a meeting, the research team expects that a planned upcoming visit will help the Commission address the lack of awareness, policies, resources, and support.

At KSU, the lack of authority and paucity of resources with potential for high impact means that self-determination becomes the dimension of empowerment with chief importance. Indeed only 2 out of 10 barriers in Table 2 have no change driver identified for self-determination (lack of campus-wide funding, and state-level educational priorities that prevent new SD programming). Among the rest, self-determination at KSU is often unsurprising in form; change drivers have been maintaining participation in SD-related events or continuing to advocate for administrative support. However, in 2017 a group of faculty opportunistically gained support (for books and travel) from the KSU's Center for Excellence in Teaching and Learning (CETL) to form a Faculty Learning Community (FLC), which has since modified its plan of work to advance SD and address multiple barriers. Initial work 
focused on addressing the lack of SD in general education curricula, and later the development and implementation of the faculty survey. These efforts are still in process and could have lasting impact over the long term. For instance, if the director position is re-established, the FLC is well poised to suggest a certificate program, and the survey results can be used as the starting point for a research clearinghouse or networking directory. The FLC also identified ways that the broader KSU faculty can enhance the resiliency of SD in the absence of authority (see Table 3). These are actions of self-determination whose impact is directly proportional to the number of individuals who carry them out.

Table 3. Approaches for faculty to enhance campus sustainability efforts in HEIs. Source: Research Team.

\begin{tabular}{|c|c|}
\hline & $\begin{array}{l}\text { Faculty Resilience } \\
\text { Approaches for Individuals and Small Groups of Faculty }\end{array}$ \\
\hline Resources & $\begin{array}{l}\text { - Observe energy, water, and materials conservation practices on campus and explain } \\
\text { them to colleagues and students } \\
\text { - } \quad \text { Pursue autonomous efforts in teaching and publication } \\
\text { Participate in university-sanctioned committee activities in departments, colleges, } \\
\text { and campus-wide situations } \\
\text { - Seek funding from external sources (e.g., sustainability-related grants } \\
\text { and fellowships) } \\
\text { - Apply for sustainability-related awards }\end{array}$ \\
\hline Academics & $\begin{array}{l}\text { - Inform oneself of disciplinary connections to sustainability } \\
\text { - Draw attention to sustainability topics in classes with examples } \\
\text { - Demonstrate relevance of discipline-specific topics and issues to sustainability } \\
\text { in classes } \\
\text { - Develop research and scholarship projects that are linked to sustainability } \\
\text { Disseminate sustainability-related research findings through conferences, symposia, } \\
\text { and publications }\end{array}$ \\
\hline Innovation & $\begin{array}{l}\text { - Highlight sustainability in department- and college-level concerns } \\
\text { - Seek ways to shift the focus of existing campus programs toward sustainability topics } \\
\text { and issues } \\
\text { - Advance sustainability through innovative research topics and teaching techniques }\end{array}$ \\
\hline Community & $\begin{array}{l}\text { - Champion sustainability on and off campus } \\
\text { - Contact like-minded faculty colleagues and share interests } \\
\text { - Identify community partners such as businesses and nonprofit groups (e.g., clubs, } \\
\text { civic groups, and churches) } \\
\text { - Promote local service-learning assignments, internship, and co-op opportunities that } \\
\text { connect to sustainability for students } \\
\text { Describe connections between sustainability and local groups, particularly as they } \\
\text { affect future careers for graduates }\end{array}$ \\
\hline Collaboration & $\begin{array}{l}\text { - } \quad \text { Undertake team teaching on sustainability topics } \\
\text { - } \quad \text { Undertake collaborative writing and research projects } \\
\text { - } \quad \text { Develop and offer interdepartmental sustainability-related workshops } \\
\text { - } \quad \text { Create ecocentric clubs for faculty } \\
\text { - }\end{array}$ \\
\hline
\end{tabular}


Verhulst and Boks include "initiative, creativity and autonomy" under self-determination [16] (p. 93). These factors tie into Brinkhurst et al.'s idea of achieving change in HEIs by empowering faculty and staff, the middle part of the organization. In fact, "the greatest potential for long-term change comes from active intrapreneurship by faculty and staff" [11] (p. 351). Understanding the complexities of HEIs, faculty and staff can act as change agents who effect change within organizational boundaries. Change at the faculty/staff level is "'middle-out' change" or transformative change from within [11] (p. 340). Faculty, however, differ from staff in terms of expertise and specialization. As specialists who can understand and relay technical information, faculty are "'transmitters' of implementation processes" [17] (p. 172). They can effect change by serving to bridge the gap between administrators and other campus agents such as staff and students [17]. As the research team discovered, faculty can also act as self-sufficient innovators-change agents who take it upon themselves to introduce micro-change and push for macro-change.

\section{Limitations and Future Research}

At KSU, the process model suggested that, given the lack of authority and resources, self-determination is the most promising dimension of empowerment; therefore, expectations for advancing change should be tempered for the time being. However, there are several caveats to this outcome. While the process model captured some of the complexity of the change process in HEIs, it does not consider all university stakeholders (e.g., academic staff, plant operations staff, students, etc.). The selected framework focused on change driven by the middle rungs-only faculty. The role of staff still needs to be considered [17]. For example, feedback from academic and plant operations staff as well as from students will provide a more comprehensive look at barriers and change drivers from the perspective of all stakeholders at the institution. The reinstatement of authority figures such as the director of sustainability, or increased advancement of SD from senior administrators, could rapidly eliminate barriers and shift the expectations for change. KSU's leadership has changed rapidly in the last few years, and there is no indication that it has stabilized. Indeed, the model's outcomes were dependent upon the choice of framework used for identifying barriers and change drivers. Frameworks focusing on other aspects of organizational change may lead to different conclusions. A Socio-Technical Systems Thinking framework, for example, may be particularly suited for SD in HEIs, given the complexity of both sustainability and institutions of higher learning (for an overview, see Davis and Coan [5]). Ideally, HEIs should evaluate their progress toward SD through multiple frameworks. Though the discovery process is essentially the same, other HEIs may find alternative frameworks more suitable. Additionally, the organizational culture [29] and the types of change (e.g., planned versus emergent versus contingency) [5] sought may influence an HEI's chosen approach.

Finally, once the discovery process is complete, the next phase is discipline-based planning where faculty are rapidly brought up to speed regarding SD, including the results of discovery and the contributions of SD early adopters (for a discussion of the steps following the discovery phase, see Chambers, 2013) [30]. Although the discovery process may receive re-evaluation and re-iteration if its outcomes somehow do not lend themselves toward discipline-based planning, in the case of KSU, the process model has yielded useful information for advancing SD (Table 2).

\section{Conclusions}

The intellectual project of this work began with an effort to strategically advance SD in one HEI in order to overcome perennial and new barriers to establish an integrated program encompassing operations, administration, and academics. Though the research team initially thought that KSU's $\mathrm{SD}$ experience of setbacks and challenges was unique, it discovered that, though the details were individualized to the institution, the arch of the project was not atypical. Consequently, the search for an approach to respond to current circumstances revealed how much the team could learn from others' similar struggles and, further, the change-management literature they had generated. This work 
is intended to provide others with a way to analyze an HEI's distinctive situation thoroughly and dispassionately, producing new insights into the available change drivers and specific behaviors and actions that SD change agents should adopt to enable success. As Neil B. Weissman explains in the Association for American Colleges and Universities' journal Liberal Education,

Experts in careers related to sustainability particularly require the ability to constantly remake their technical training in an arena in which successful strategies must be flexible and adaptive. Moreover, the integrative nature of sustainability challenges gives rise to a demand for "translators," professionals with the understanding and communication skills to carry knowledge across the boundaries that divide communities of experts, policy makers, and the public. [31] (p. 8)

Though its proponents see SD as an obvious priority in a twenty-first-century university, others may not. Proponents must translate the value and relevance of SD for others. To do so, they must adopt proactive resilience as an approach. Just as an individual person makes changes in behaviors and routines incrementally to support the sustainability of the planet and all its species, shifts toward academic sustainability should be expected to occur gradually as well. If an institution truly wants to meet the needs of its time, essential re-imaginings of traditional approaches to fulfilling its mission will follow. Vijaya Deshmukh lists the breadth of the goals that pertain to SD and must be pursued through collaboration and sharing; these include

[i]ntegrating actions of conservation and human development, satisfying basic human needs, achieving equality and social justice for all, facilitating social self-determination and cultural diversity, managing legacy for future generations, maintaining ecological integrity, [and] developing new technologies and product manufacturing processes. [32] (p. 3)

These are obviously goals in keeping with the mission of most HEIs, so proponents need to make the case and make it as desirable as possible for those with authority to invest in SD.

Author Contributions: E.E.A.II., E.G., D.G., A.G., M.K.H., V.S.-F., and M.W. contributed equally to the paper.

Funding: Funding for this research was provided by the Kennesaw State University Center for Excellence in Teaching and Learning (CETL), the College of Humanities and Social Sciences, the College of Science and Mathematics, and the College of Architecture and Construction Management.

Acknowledgments: We gratefully acknowledge Kennesaw State University's Center for Excellence in Teaching and Learning (CETL) for its support of the Sustainability Faculty Learning Community (FLC) during AY 2017 and AY 2018. CETL supplied research materials and travel funding to the members of the FLC. In addition, we acknowledge the support and encouragement of the members of KSU's Presidential Commission on Sustainability as well as the Office of Diversity and Inclusion, longstanding proponents of campus sustainability initiatives.

Conflicts of Interest: The authors declare no conflict of interest.

\section{References}

1. Scott, G.; Tilbury, D.; Sharp, L.; Deane, E. Turnaround Leadership for Sustainability in Higher Education: Executive Summary 2012; Department of Industry, Innovation, Science, Research and Tertiary Education, Australian Government Office for Learning and Teaching: Sydney, NSW, Australia, 2012; pp. 1-21; ISBN 978-1-922218-01-8.

2. Robertson, J.L.; Barling, J. Greening Organizations through Leaders' Influence on Employees' Pro-environmental Behaviors. J. Organ. Behav. 2013, 34, 176-194. [CrossRef]

3. Robertson, J.L.; Barling, J. The Role of Leadership in Promoting Workplace Pro-environmental Behaviors. In The Psychology of Green Organizations, 1st ed.; Robertson, J.L., Barling, J., Eds.; Oxford University Press: New York, NY, USA, 2015; pp. 164-186; ISBN 978-0-19-999748-0.

4. Robertson, J.L.; Carleton, E. Uncovering How and When Environmental Leadership Affects Employees' Voluntary Pro-environmental Behavior. J. Leadersh. Organ. Stud. 2018, 25, 197-210. [CrossRef]

5. Davis, M.; Coan, P. Organizational Change. In The Psychology of Green Organizations, 1st ed.; Robertson, J.L., Barling, J., Eds.; Oxford University Press: New York, NY, USA, 2015; pp. 244-274; ISBN 978-0-19-999748-0. 
6. Cortese, A.D. The Critical Role of Higher Education in Creating a Sustainable Future. Plan. High. Educ. 2003, 31, 15-22. Available online: http:/ / citeseerx.ist.psu.edu/viewdoc/download?doi=10.1.1.607.6556\&rep= rep1\&type=pdf (accessed on 18 December 2018).

7. Avissar, I.; Alkaher, I.; Gan, D. The Role of Distributed Leadership in Mainstreaming Environmental Sustainability into Campus Life in an Israeli Teaching College: A Case Study. Int. J. Sustain. High. Educ. 2018, 19, 518-546. [CrossRef]

8. McMillin, J.; Dyball, R. Developing a Whole-of-University Approach to Educating for Sustainability: Linking Curriculum, Research and Sustainable Campus Operations. J. Educ. Sustain. Dev. 2009, 3, 55-64. [CrossRef]

9. Fien, J. Advancing Sustainability in Higher Education: Issues and Opportunities for Research. Int. J. Sustain. High. Educ. 2002, 3, 243-253. [CrossRef]

10. Lozano, R.; Lukman, R.; Lozano, F.J.; Huisingh, D.; Lambrechts, W. Declarations for Sustainability in Higher Education: Becoming Better Leaders, through Addressing the University System. J. Clean. Prod. 2013, 48, 10-19. [CrossRef]

11. Brinkhurst, M.; Rose, P.; Maurice, G.; Ackerman, J.D. Achieving Campus Sustainability: Top-down, Bottom-up, or Neither? Int. J. Sustain. High. Educ. 2011, 12, 338-354. [CrossRef]

12. Aleixo, A.M.; Leal, S.; Azeiteiro, U.M. Conceptualization of Sustainable Higher Education Institutions, Roles, Barriers, and Challenges for Sustainability: An Exploratory Study in Portugal. J. Clean. Prod. 2018, 172, 1664-1673. [CrossRef]

13. Verhulst, E.; Lambrechts, W. Fostering the Incorporation of Sustainable Development in Higher Education. Lessons Learned from a Change Management Perspective. J. Clean. Prod. 2015, 106, 189-204. [CrossRef]

14. Verhulst, E. The Human Side of Sustainable Design Implementation from the Perspective of Change Management. Doctoral Thesis, University of Antwerp, Antwerp, Belgium, 2012.

15. Lambrechts, W.; Verhulst, E.; Rymenams, S. Professional Development of Sustainability Competences in Higher Education: The Role of Empowerment. Int. J. Sustain. High. Educ. 2017, 18, 697-714. [CrossRef]

16. Verhulst, E.; Boks, C. Employee Empowerment for Sustainable Design. J. Corp. Citizen. 2014, 55, 73-101. Available online: https:/ / www.jstor.org/stable/jcorpciti.55.73 (accessed on 18 December 2018). [CrossRef]

17. Barth, M. Many Roads Lead to Sustainability: A Process-Oriented Analysis of Change in Higher Education. Int. J. Sustain. High. Educ. 2013, 14, 160-175. [CrossRef]

18. Rodriguez, Y.R.C. Paul: "Father of Sustainability". 2013. Available online: http://news.kennesaw.edu/ stories/2013/RC-Paul-Father-of-Sustainability.php (accessed on 18 December 2018).

19. AASHE (The Association for the Advancement of Sustainability in Higher Education). Beyond the Right Thing to Do: The Value of Sustainability in Higher Education. 2017, pp. 1-5. Available online: http:/ / www.aashe. org/wp-content/uploads/2017/10/AASHE_2017_BeyondRightThingToDo_Brochure.pdf (accessed on 18 December 2018).

20. George, A.L.; Bennett, A. Case Studies and Theory Development in the Social Sciences, 1st ed.; MIT Press: Cambridge, MA, USA, 2005; ISBN 0-262-57222-2.

21. Hoover, E.; Harder, M.K. What Lies Beneath the Surface? The Hidden Complexities of Organizational Change for Sustainability in Higher Education. J. Clean. Prod. 2015, 106, 175-188. [CrossRef]

22. Corcoran, P.B.; Walker, K.E.; Wals, A.E.J. Case Studies, Make-your-case Studies, and Case Stories: A Critique of Case-study Methodology in Sustainability in Higher Education. Environ. Educ. Res. 2004, 10, 7-21. [CrossRef]

23. Merriam, S.B. Qualitative Research and Case Study Applications in Education, Revised and Expanded from Case Study Research in Education, 2nd ed.; Jossey-Bass Publishers: San Francisco, CA, USA, 1998; ISBN 0-7879-1009-0.

24. Yin, R.K. Case Study Research Design and Methods, 2nd ed.; Sage Publications: Newbury Park, CA, USA, 1989; ISBN 0-8039-3471-8.

25. Barth, M. Implementing Sustainability in Higher Education, 1st ed.; Routledge: New York, NY, USA, 2015; ISBN 978-0-415-83374-5.

26. Barlett, P.F.; Chase, G.W. Sustainability in Higher Education: Stories and Strategies for Transformation, 1st ed.; MIT Press: Cambridge, MA, USA, 2013; ISBN 978-0-262-51965-6.

27. Thomashow, M. The Nine Elements of a Sustainable Campus, 1st ed.; MIT Press: Cambridge, MA, USA, 2014; ISBN 978-0-262-02711-3.

28. Kennesaw State University. We Prepare Students for Better Lives. 2018-2023 Strategic Plan. Available online: https:/ / planning.kennesaw.edu/docs /KSU_StratplanLettersize_p2A.pdf (accessed on 18 December 2018). 
29. Weick, K.E.; Quinn, R.E. Organizational Change and Development. Ann. Rev. Psych. 1999, 50, $361-386$. [CrossRef] [PubMed]

30. Chambers, D.P. A Discipline-Based Model for Embedding Sustainability in University Curricula. In Sustainability Assessment Tools in Higher Education Institutions: Mapping Trends and Good Practices around the world, 1st ed.; Caeiro, S., Filho, W.L., Jabbour, C., Azeiteiro, U.M., Eds.; Springer International Publishing: Cham, Switzerland, 2013; pp. 309-321; ISBN 978-3-319-02374-8.

31. Weissman, N.B. Sustainability and Liberal Education: Partners by Nature. Lib. Educ. 2012, 98, 6-13. Available online: https://www.aacu.org/publications-research/periodicals/sustainability-liberaleducation-partners-nature (accessed on 18 December 2018).

32. Deshmukh, V. Achieving Resiliency through Sustainable Literacy. In Handbook of Theory and Practice of Sustainable Development in Higher Education, 1st ed.; Filho, W.L., Azeiteiro, U.M., Alves, F., Molthan-Hill, P., Eds.; Springer International Publishing: Cham, Switzerland, 2017; Volume 4, pp. 3-13; ISBN 978-3-319-47876-0.

(C) 2019 by the authors. Licensee MDPI, Basel, Switzerland. This article is an open access article distributed under the terms and conditions of the Creative Commons Attribution (CC BY) license (http:/ / creativecommons.org/licenses/by/4.0/). 